\title{
Infiltrate of syphilitic lesions before and after
} treatment

\author{
A TOSCA, J LEHOU, M HATJIVASILIOU, A VARELZIDIS, JD STRATIGOS
}

From the Department of Dermatology, "Andreas Sygros" Hospital, School of Medicine, National University of Athens, Athens, Greece

SUMMARY An immunohistological study of skin biopsy specimens from patients with early syphilis was undertaken before and after treatment (one day after intramuscular administration of $2 \cdot 4$ MIU benzathine penicillin and eight days later, after a total administration of 3.6 MIU.

In chancres from seronegative patients treatment with 3.6 MIU usually resulted in fewer immunocompetent cells in the infiltrate. In lesions of secondary syphilis treatment with $2.4 \mathrm{MIU}$ benzathine penicillin produced a significant decrease in immunocompetent cells. After treatment with 3.6 MIU there was no further decrease. It was worth noticing that even eight to nine days after the initial pretreatment biopsy, when 3.6 MIU had been administered, the overall lymphohistiocytic infiltrate was not substantially diminished. Significantly more suppressor $\left(\mathrm{T}^{+}\right)$cells were found in lesions of primary syphilis than of secondary syphilis, and they showed remarkable exocytosis. Activated local $\mathrm{T}^{+}$cells may release immunosuppressive lymphokines.

\begin{abstract}
Abundant evidence suggests that Treponema pallidum escapes humoral immune defence, although the host produces antibodies early in the infection. Heterologous antibodies are diagnostic evidence of syphilis and indicate polyclonal activation of B lymphocytes. Conflicting results have been reported concerning cell mediated immunity status at different stages of the disease. Badanoiu et al, 'Janot et al, ${ }^{2}$ and Schell and Musher, ${ }^{3}$ are among the workers who have produced evidence of good in vitro cellular immune response against $T$ pallidum. Other studies of delayed type hypersensitivity and inhibited leucocyte migration have indicated diminished cell mediated immunity to $T$ pallidum in early syphilis. ${ }^{48} \mathrm{Gschnait} e t$ al have claimed that hitherto undetermined serum factors possibly block the immune system in the blood of patients with syphilis. $^{8}$

In the study reported here we examined the identity of mononuclear cells and subsets that made up the lesional infiltrate at different stages of syphilis, both before and after penicillin administration, and speculated on the local pathogenetic mechanisms during the course of the disease.
\end{abstract}

Address for reprints: Dr A D Tosca, Department of Dermatology, "Andreas Sygros" Hospital, 5 Dragumi Street, Kesariani 16121 , Athens, Greece

Accepted for publication 4 April 1988

\section{Patients, materials, and methods}

We studied skin biopsy specimens from 40 patients with early syphilitic lesions who were divided into four groups. Group 1 consisted of 11 with primary syphilis who were seronegative but dark field positive. Group 2a consisted of six similar patients 24 hours after they had received an intramuscular injection of 2.4 MIU benzathine penicillin. Group $2 b$ consisted of four similar patients after intramuscular administration of a total of 3.6 MIU. Group 3 consisted of 11 patients with secondary syphilis (six with macular, and five with papular lesions) who were seropositive in the quantitative Venereal Disease Research Laboratory (VDRL), Wassermann, and fluorescent treponemal antibody absorption (FTA-ABS) (IgG and IgM) tests and the $T$ pallidum haemagglutination assay (TPHA). Group 4a consisted of five patients similar to those in group 324 hours after receiving 2.4 MIU benzathine penicillin. Group $4 \mathrm{~b}$ consisted of three similar patients after receiving 3.6 MIU. Both $2 \mathrm{~b}$ and $4 \mathrm{~b}$ groups were given 1-2 MIU one week after the 2.4 MIU penicillin. Patients with syphilis and positive for antibodies to HIV were excluded from the study.

The methods used were the indirect immunoperoxidase and the alkaline phosphatase anti-alkaline phosphatase (APAAP) techniques with monoclonal antibodies on $5 \mu \mathrm{m}$ cryostat sections fixed with acetone. The following antibodies were used: OKT3 
(directed towards the $\mathrm{T} 3$ complex of mature peripheral T lymphocytes), OKT4/DAKO-T4 (predominantly for helper (inducer) cells), OKT8 (for suppressor (cytotoxic) $\mathrm{T}$ lymphocytes), $\mathrm{Na}_{1} 34$ (for dendritic (mainly Langerhans') cells and activated T cells), B1 (for B cells), and OKMl (for monocytes/macrophages). OKT3, OKT4, OKT8, and OKM1 were purchased from Ortho Pharmaceutical (Raritan, New York, USA), DAKO-T4 from Dakopatts (Denmark), $\mathrm{Na}_{1} 34$ from Seralab (Sussex, England), and $\mathrm{B} 1$ from Coulter Electronics (Luton, England). The details of the indirect immunoperoxidase procedure have been described previously. ${ }^{9}$ APAAP was undertaken according to the protocol of Schaumburg-Lever. ${ }^{10}$ It was considered to be more sensitive and was used to check the results obtained with the indirect immunoperoxidase method. The results were always similar. OKT4 and DAKO-T4 gave similar results in the 12 specimens used. The percentage of cells staining positively with the "helper" antibodies was almost equal to that with peripheral $\mathrm{T}$ cell antibodies. ${ }^{911}$

The cell subpopulations in the dermal infiltrate were given as percentages of lymphoid cells. Dendritic cells in the epidermis $\left(\mathrm{Na}_{1} 34^{+}\right)$were counted using an ocular micrometer (Zeiss, WKPL, 10 $x$ ) on a light microscope ( $\times 400$ magnification) and were expressed as cells $/ \mathrm{mm}^{2}$ epidermal cell surface.

The histological results were evaluated as intense disperse perivascular infiltrate, perivascular and in the dermal papillae, perivascular infiltrate only, or negative.

Cellular components were classified as $(+++)$ if the cell type predominated in the infiltrate, $(++)$ if there were many cells, $(+)$ if they could be observed in adequate numbers, $( \pm)$ if they were rarely observed, and $(-)$ if there were none.

Statistical analyses were undertaken using the Wilcoxon rank sum test.

\section{Results}

From the histological study (table 1) vertical correla-

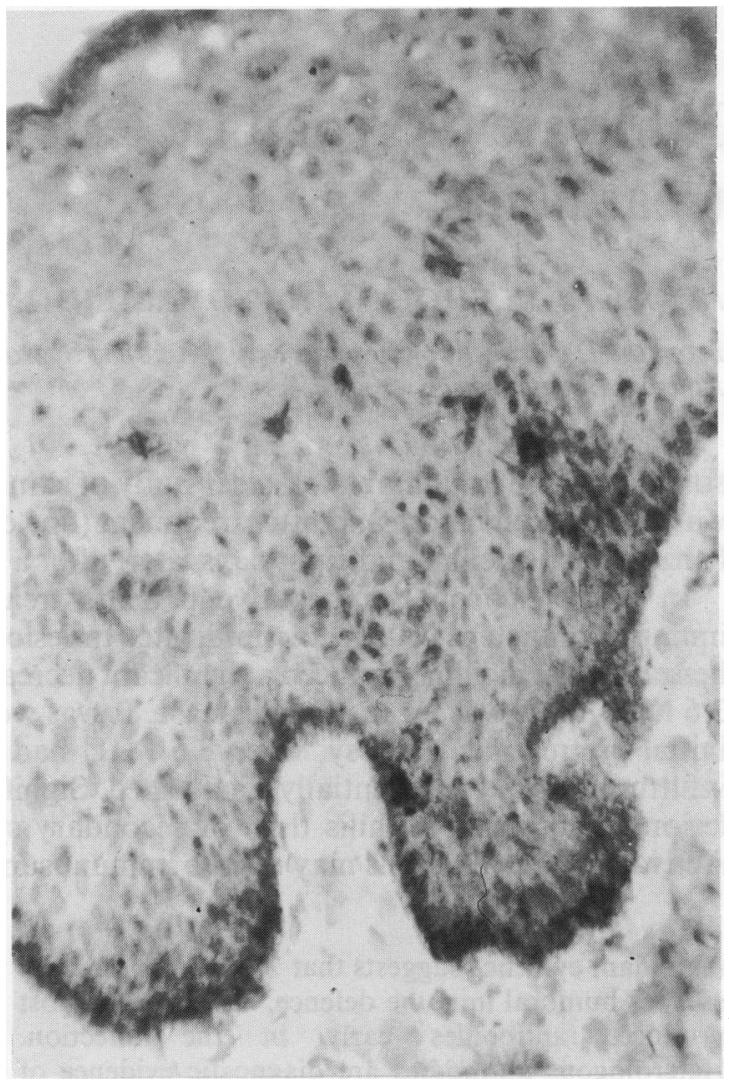

Fig 1 Exocytosis of $\mathrm{T}^{+}$cells into epidermis of papule from patient with untreated primary syphilis. (Alkaline phosphatase anti-alkaline phosphatase.)

tion between groups did not show significant differences, except that significantly $(p<0.05)$ fewer plasma cells were found in group $2 b$ than in group 1 . More plasma cells were found in group 3, although not significantly more than in group 1 .

The lymphohistiocytic infiltrate was mainly

Table 1 Histological findings (figures show mean (SD) positivity graded on an arbitrary scale from 0 to 4)

\begin{tabular}{|c|c|c|c|c|c|c|c|}
\hline Group & No & Infiltrate & Lymphocytes & $\begin{array}{l}\text { Macrophages } \\
\text { (histiocytes) }\end{array}$ & Plasma cells & Polymorphs & Eosinophils \\
\hline $\begin{array}{l}1 \\
2 \mathrm{a} \\
2 \mathrm{~b} \\
3 \\
4 \mathrm{a} \\
4 \mathrm{~b}\end{array}$ & $\begin{array}{r}11 \\
5 \\
4 \\
13^{*} \\
5 \\
3\end{array}$ & $\begin{array}{l}3.00(1.09) \\
3.00(0.89) \\
2.50(0.87) \\
2.76(1.09) \\
2.00(0.63) \\
2.34(0.47)\end{array}$ & $\begin{array}{l}2.73(1.11) \\
2.80(0.98) \\
2.00(0) \\
2.85(1.07) \\
1.80(0.75) \\
2.67(0.47)\end{array}$ & $\begin{array}{l}2.09(0.83) \\
2.20(0.40) \\
2.20(1.08) \\
2.29(0.72) \\
1.80(0.40) \\
2.34(0.47)\end{array}$ & $\begin{array}{l}2.18(1.33) \\
2.40(0.80) \\
1.00(0.71) \\
2.46(0.96) \\
1.80(0.75) \\
1.34(0.47)\end{array}$ & $\begin{array}{l}0.18(0.40) \\
0 \\
0.25(0.43) \\
0.54(0.66) \\
0 \\
0.34(0.47)\end{array}$ & $\begin{array}{l}0 \\
0 \\
0 \\
0 \cdot 34(0.49) \\
0 \cdot 40(0.49) \\
0\end{array}$ \\
\hline
\end{tabular}

Groups 1 and 2 = patients with primary syphilis, group $2 \mathrm{a} 24$ hours after receiving 2.4 MIU benzathine penicillin, group $2 \mathrm{~b}$ after receiving 3.6 MIU; groups 3 and $4=$ patients with secondary syphilis, group 4 a 24 hours after receiving 2.4 MIU, group 4 b after receiving 3.6 MIU. The presence of polymorphs and eosinophils was not correlated.

*Two additional group 3 specimens included in histological study only. 
Table 2 Semiquantitative immunohistochemical findings (figures show mean (SD) percentages of lymphoid cells except where shown)

\begin{tabular}{|c|c|c|c|c|c|c|c|c|}
\hline \multirow[b]{2}{*}{ Group } & \multirow[b]{2}{*}{ No } & \multirow[b]{2}{*}{$\mathrm{T3}^{+}$} & \multirow[b]{2}{*}{$T 4^{+}$} & \multirow[b]{2}{*}{$T 8^{+}$} & \multirow[b]{2}{*}{$B I^{+}$} & \multirow[b]{2}{*}{$O K M I^{+}$} & \multicolumn{2}{|l|}{$N a_{1} 34^{+}$} \\
\hline & & & & & & & $\begin{array}{l}\text { Epidermal } \\
\left(\text { cells } / \mathrm{mm}^{2}\right)\end{array}$ & Dermal \\
\hline $\begin{array}{l}1 \\
2 \mathrm{a} \\
2 \mathrm{~b} \\
3 \\
4 \mathrm{a} \\
4 \mathrm{~b}\end{array}$ & $\begin{array}{r}11^{*} \\
6 \\
4 \\
11 \\
5 \\
3\end{array}$ & $\begin{array}{l}31.78(9.53) \\
23.60(9.62) \\
13.87(8.08) \\
37.99(14.72) \\
18.31(11.00) \\
25.00(8 \cdot 16)\end{array}$ & $\begin{array}{l}41.36(16.50) \\
20.65(9.36) \\
16.28(5.53) \\
34.46(13.80) \\
18.02(15.64) \\
25.53(5.92)\end{array}$ & $\begin{array}{c}29.20(10.84) \\
26.44(11.08) \\
7.49(1.06) \\
44.84(10.75) \\
23.00(14.89) \\
28.89(2.61)\end{array}$ & $\begin{array}{c}19.04(18 \cdot 15) \\
20 \cdot 12(7 \cdot 75) \\
3.26(6 \cdot 52) \\
39 \cdot 50(17 \cdot 16) \\
24 \cdot 11(18 \cdot 15) \\
8.33(11 \cdot 78)\end{array}$ & $\begin{array}{c}24.34(15.19) \\
14.12(10.61) \\
19.85(10.69) \\
21.56(12.33) \\
9.37(9.76) \\
14.97(9.11)\end{array}$ & $\begin{array}{l}269.05(155.28) \\
177.40(187.30) \\
197.67(140.00) \\
341.80(276.90) \\
288.00(202.79) \\
195.40(98.50)\end{array}$ & $\begin{array}{c}19.37(14.00) \\
18.98(11.56) \\
9.54(6.44) \\
29.00(17.50) \\
4.70(5.76) \\
5.87(4.17)\end{array}$ \\
\hline
\end{tabular}

See footnote of table 1 for descriptions of groups.

Results not available from one group 1 patient for $\mathrm{B}^{+}$and $\mathrm{Na}_{1} 34^{+}$.

subepidermal and perivascular, and it persisted even after treatment with $3.6 \mathrm{MIU}$ penicillin.

The immunohistochemical study showed a characteristic exocytosis of $\mathrm{T}^{+}$cells (fig 1 ) that was prominent mainly before treatment. Minor exocytosis of $\mathrm{T}^{+}$, $\mathrm{T}^{+}$, and $\mathrm{OKM1}^{+}$cells could be observed in some cases. Dermal $\mathrm{Na}_{1} 34^{+}$cells were predominantly lymphoid, although dendritic cells could also be observed in the upper dermis.

Table 2 shows semiquantitative analysis of the data obtained. Differences between groups 1 and $2 a$ were significant regarding $\mathrm{T}^{+}$cells $(\mathrm{p}<0.05)$ and showed a trend towards significance for $\mathrm{T}^{+}$and $\mathrm{OKM} 1^{+}$cells and $\mathrm{Na}_{1} 34^{+}$epidermal dendritic cells. Group $2 \mathrm{~b}$ had significantly fewer $\mathrm{T}^{+}$and $\mathrm{T} 4^{+}(\mathrm{p}<0.05), \mathrm{T}^{+}(\mathrm{p} \simeq$ $0.05)$, and $\mathrm{B1}^{+}(\mathrm{p}<0.01)$ cells than group 1 , and $\mathrm{Na}_{1} 34^{+}$dermal cells showed a trend towards decrease without reaching significance. The decrease in $\mathrm{T}^{+}$and $\mathrm{Bl}^{+}$cells in group $2 \mathrm{~b}$ was significant even compared with group $2 \mathrm{a}$ ( $\mathrm{p} \simeq 0.05$ and $\mathrm{p}<0.01$, respectively).

Comparison between (untreated) groups 1 and 3 showed significantly more $\mathrm{T}^{+}$cells $(\mathrm{p}<0.01)($ fig 2$)$ and $\mathrm{B}^{+}$cells $(\mathrm{p}<0.05)$ in group 3 and a trend towards more dendritric epidermal cells.

Significantly fewer $\mathrm{T}^{+}(\mathrm{p} \simeq 0.05), \mathrm{T}^{+}(\mathrm{p}<0.05)$, and $\mathrm{Na}_{1} 34^{+}$dermal cells $(\mathrm{p}<0.01)$ were seen in group

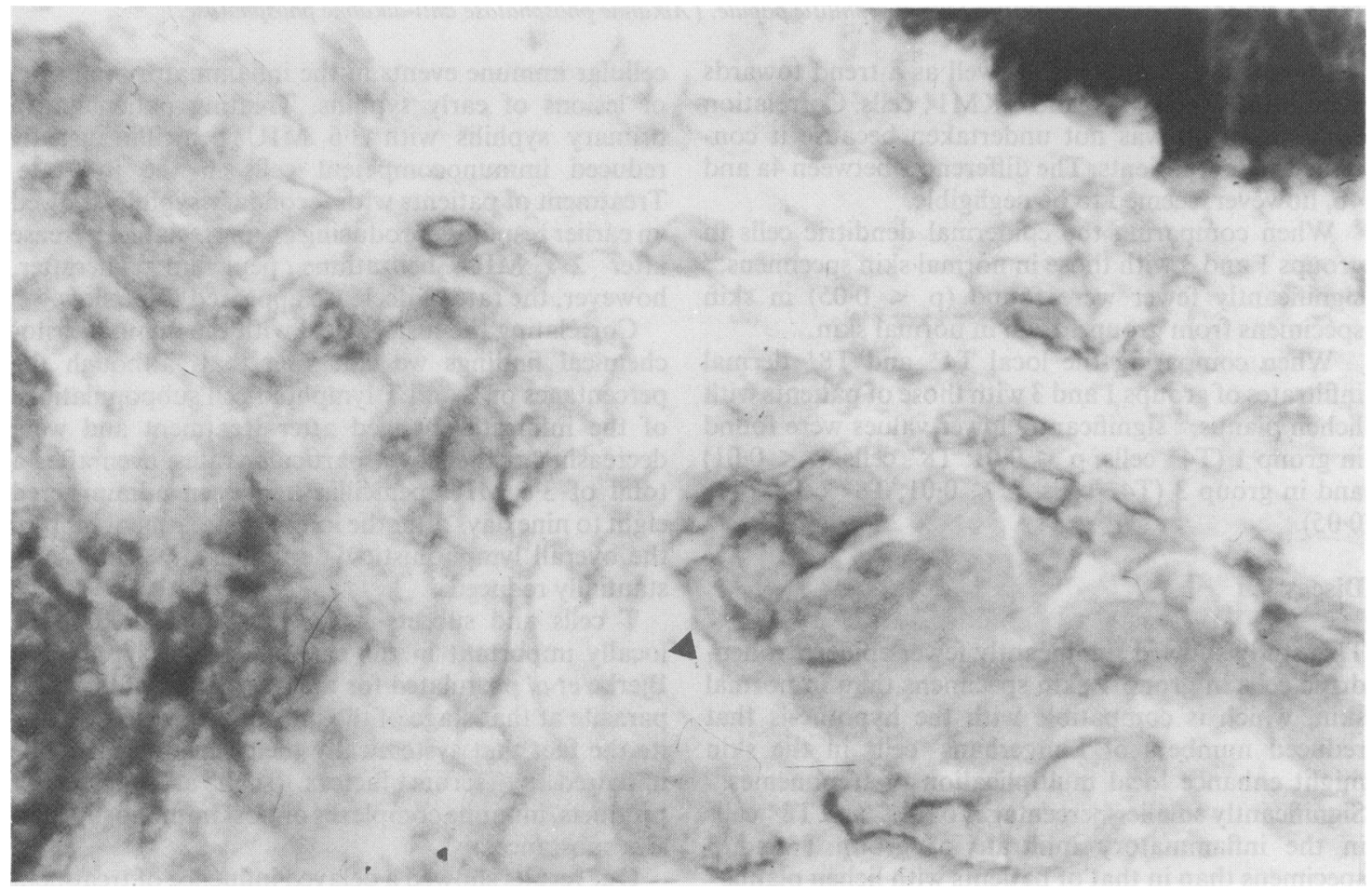

Fig 2 Disperse $\mathrm{T}^{+}$cells in dermal infiltrate of syphilitic papule. (Alkaline phosphatase anti-alkaline phosphatase.) 


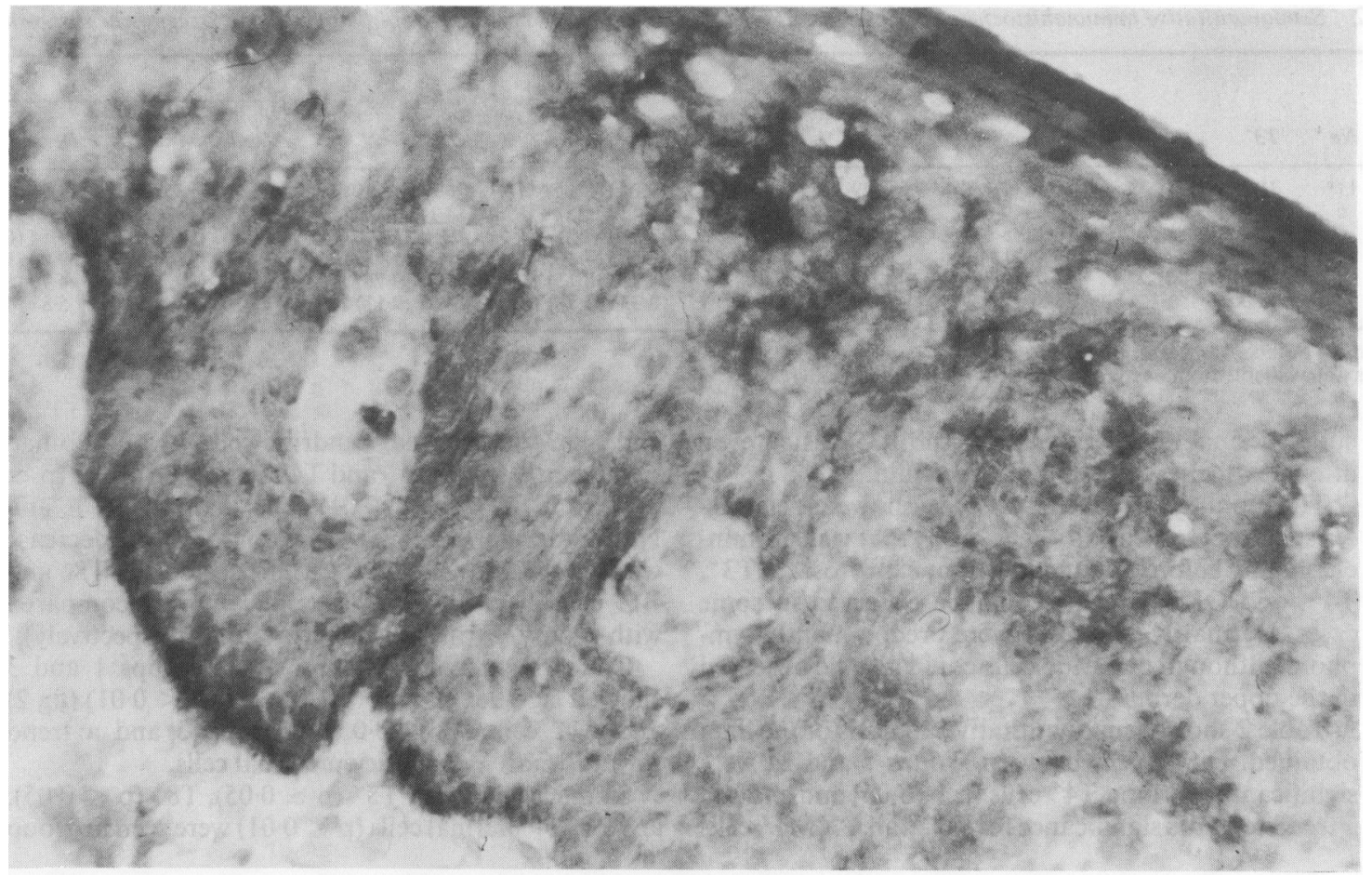

Fig $3 \mathrm{Na}_{1} 34^{+}$epidermal dendritric cells in syphilitic papule. (Alkaline phosphatase anti-alkaline phosphatase.)

4a than group 3 patients, as well as a trend towards significantly fewer $\mathrm{T}^{+}{ }^{+}$and $\mathrm{OKM}{ }^{+}$cells. Correlation with group $4 \mathrm{~b}$ was not undertaken because it contained so few patients. The differences between $4 a$ and $4 \mathrm{~b}$, however, seemed to be negligible.

When comparing the epidermal denditric cells in groups 1 and 3 with those in normal skin specimens, ${ }^{12}$ significantly fewer were found $(p<0.05)$ in skin specimens from group 1 than in normal skin.

When comparing the local $\mathrm{T}^{+}$and $\mathrm{T}^{+}$dermal infiltrates of groups 1 and 3 with those of patients with lichen planus, ${ }^{13}$ significantly lower values were found in group $1\left(\mathrm{~T}^{+}\right.$cells, $\mathrm{p}<0.01 ; \mathrm{T}^{+}$cells, $\left.\mathrm{p}<0.01\right)$ and in group $3\left(\mathrm{~T}^{+}\right.$cells, $\mathrm{p}<0.01 ; \mathrm{T}^{+}$cells, $\mathrm{p} \simeq$ 0.05).

\section{Discussion}

This study showed significantly fewer epidermal dendritic cells in group 1 skin specimens than in normal skin, which is compatible with the hypothesis that reduced numbers of Langerhans' cells in the skin might enhance local multiplication of treponemes. ${ }^{14}$ Significantly smaller percentages of $\mathrm{T}^{+}$and $\mathrm{T}^{+}$cells in the inflammatory infiltrate of group 1 and 3 specimens than in that of patients with lichen planus ${ }^{13}$ favours the hypothesis of somehow decreased local cellular immune events in the inflammatory infiltrate of lesions of early syphilis. Treating patients with primary syphilis with 3.6 MIU penicillin usually reduced immunocompetent cells in the infiltrate. Treatment of patients with secondary syphilis showed an earlier response, producing an appreciable decrease after 2.4 MIU benzathine penicillin. Therafter, however, the rate of decrease appeared to be slow.

Correlating the histological with the immunohistochemical findings we can seen that, although the percentages of $B$ and $T$ lymphoid cell subpopulations of the infiltrate changed after treatment and were decreasing at their own particular rates, even after a total of 3.6 MIU penicillin had been administered eight to nine days after the initial pretreatment biopsy, the overall lymphohistiocytic infiltrate was not substantially reduced.

$T$ cells and subsets have been considered to be locally important in the early stages of syphilis, as Bjerke et al postulated for the interaction of host and parasite at that stage of the infectious process, ${ }^{15}$ despite the fact that systemically their function might be impaired by serum factors (such as spirochaete products, immune complexes or host immunosuppressive substances).

Our results showed a delayed influence of treatment on locally distributed immunocompetent cells. This is 
consistent with the results of Friedman and Türk who found that people undergoing treatment with drugs showed pronounced lymphocytic reactivity to the $T$ pallidum antigen. ${ }^{16}$

In syphilis, $T$ pallidum stimulates local cell mediated immunity that leads to its elimination. ${ }^{3}$ Macrophages helped by Langerhans' cells undertake phagocytosis and process the antigen, which has specific biological properties. Moreover the spirochaete is protected by a mucoid envelope that prevents its being engulfed by phagocytic cells or those presenting antigen. Jensen and From have suggested that macrophages are inhibited by infected $\mathrm{T}$ cells, which render $\mathrm{C} 3 \beta$ receptors unavailable for processing antibody complement opsonised treponemes. ${ }^{17}$

More $\mathrm{Na}_{1} 34^{+}$epidermal dendritic cells (fig 3 ) were found in patients with secondary than primary syphilis. This was consistent with the findings of Mittag and Klingmüller, who also found several Langerhans' cells in one patient with granulomatous syphilis (a transitional stage between early and late syphilis). ${ }^{14}$ They considered that the interaction of Langerhans' cells with intraepidermal $T$ pallidum might be important for the epidermotropic infiltration.

Decreased numbers of circulating suppressor cells have been reported in secondary syphilis, ${ }^{18}$ which may partly account for the increased amount of heterologous antibodies during this stage. The relative increase in locally distributed $\mathrm{T}^{+}$cells at this stage (fig 2) might be related to the decrease in blood, because of the peripheral distribution of lymphocytes in selective tissues. ${ }^{19}$ Increased $\mathrm{T}^{+}$cells possibly release immunosuppressive lymphokines ${ }^{20}$ locally and into the blood stream, giving the invading micro-organism an advantage for long term survival. ${ }^{8}$ This, in conjunction with local antibody releasing cells (B cells and plasma cells) might explain the serological findings in advanced primary or secondary syphilis.

\section{References}

1 Badanoiu A, Gavrilesco M, Nicolau G, Circiumaresco T. Lymphoblastogenèse immunoallergique et antigène trépon- emique in vitro dans la syphilis. Arch Roum Pathol Exp Microbiol 1969;28:419-27.

2 Janot C, Grandidier M, Pupil P, Thomas JL, Berney J, de Lavergne $\mathrm{E}$. Le test de transformation lymphoblastique au cours de la syphilis. Presse Médicale 1971;79:1901-4.

3 Schell RF, Muscher DM. Detection of non-specific resistance to Listeria monocytogenes in rabbits infected with Treponema pallidum. Infect Immun 1974;9:658-62.

4 Wright DJM, Grimble AGS. Why is the infectious stage of syphilis prolonged? British Journal of Venereal Diseases 1974;50:45-9.

5 From E, Thestrup-Pedersen K, Thulin H. Reactivity of lymphocytes from patients with syphilis towards Treponema pallidum antigen in the leucocyte migration and lymphocyte migration tests. British Journal of Venereal Diseases 1976;52:224-9.

6 Fulford KWM, Brostoff J. Leucocyte migration and cell mediated immunity in syphilis. British Journal of Venereal Diseases 1972;48:483-8.

7 Pavia CS, Folds JD, Baseman JB. Cell-mediated immunity during syphilis. British Journal of Venereal Diseases 1978;54:144-50.

8 Gschnait F, Schoenwald F, Schidt BL, Luger A. Laboratory evidence for impaired cellular immunity in different stages of syphilis. J Invest Dermatol 1982;79:40-1.

9 Tosca AD, Vareltzidis AG, Economidou J, Stratigos JD. Mycosis fungoides: evaluation of immunohistochemical criteria for the early diagnosis of the disease and differentiation between stages. J Am Acad Dermatol 1986;15:237-45.

10 Schaumburg-Lever G. Immunoenzyme techniques in dermatopathology. Int J Dermatol 1986;25:217-23.

11 McMillan EM, Wasik R, Beeman K, Everett MA. In situ immunologic phenotyping of mycosis fungoides. $J$ Am Acad Dermatol 1982;6:888-97.

12 Tosca A, Pantelaios D, Vareltzidis A, Stratigos JD. Dendritic cells in skin cancer. Skin Cancer 1986;2:117-23.

13 Tosca A, Vareltzidis A, Michalopoulos M, Georgala S, Stratigos JD. In situ identification of mononuclear cells in lichen planus. Dermatologica 1983;167:113-20.

14 Mittag H, Klingmüller G. Langerhans cells in granulomatous syphilis. Arch Dermatol Res 1983;275:190-6.

15 Bjerke JR, Krogh HK, Matre R. In situ identification of mononuclear cells in cutaneous infiltrates in discoid lupus erythematosus, sarcoidosis and secondary syphilis. Acta Derm Venereal (Stock) 1981;61:371-80.

16 Friedman PS, Türk JL. A spectrum of lymphocyte responsiveness in human syphilis. Clin Exp Immunol 1975;21:59-64.

17 Tabor DR, Azadegan AA, Schell RF, Lefrock JL. Inhibition of macrophage $C 3 \beta$-mediated ingestion by syphilitic hamster $T$ cell-enriched fractions. $J$ Immunol 1984;135:2698-704.

18 Jensen JR, From E. Alterations in $T$ lymphocytes and T-lymphocyte subpopulations in patients with syphilis. British Journal of Venereal Diseases 1982;58:18-22.

19 Turner DR, Wright DJM. Lymphadenopathy in early syphilis. J Pathol 1973;110:305-8.

20 Moretta M, Mingari MC, Santali D, Perlman P, Moretta L. Human T-lymphocyte subpopulations: alterations in systemic lupus erythematosus. Scand J Immunol 1979;10:223-8. 